\title{
Aucula magnifica (Schaus, 1904) (Lepidoptera: Noctuidae: Agaristinae): morphology of egg and last instar larvae
}

\author{
Poletto, G. ${ }^{\mathrm{a}}$, Benedetti, AJ. ${ }^{\mathrm{a}}$, Barros, NM. ${ }^{\mathrm{b}}$, Vargas, LRB. ${ }^{\mathrm{b}}$ and Specht, A. ${ }^{\mathrm{a}, \mathrm{b} *}$ \\ áLaboratório de Biologia, Centro de Ciências Exatas, da Natureza e de Tecnologia - CENT, \\ Campus Universitário da Região dos Vinhedos - CARVI, Universidade de Caxias do Sul - UCS, \\ CP 32, CEP 95700-000, Bento Gonçalves, RS, Brazil \\ ${ }^{\mathrm{b}}$ Instituto de Biotecnologia, Universidade de Caxias do Sul - UCS, \\ CP 1352, CEP 95070-560, Caxias do Sul, RS, Brazil \\ *e-mail: spechta@terra.com.br
}

Received October 28, 2008 - Acepted January 26, 2009 - Distributed May 31, 2010

(With 18 figures)

\begin{abstract}
Aiming to contribute to knowledge of the immature instars of Neotropical Lepidoptera, this study details the morphology of the egg and last instar larvae of Aucula magnifica (Schaus, 1904) (Lepidoptera: Noctuidae: Agaristinae), emphasising the structures of the corium and the chaetotaxy. There is also a report of the occurrence of entomopathogenic action of Nomuraea rileyi (Farlow) Samson fungi on the larva.
\end{abstract}

Keywords: caterpillar, entomopathogenic fungi, morphology, chaetotaxy.

\section{Aucula magnifica (Schaus, 1904) (Lepidoptera: Noctuidae: Agaristinae): morfologia do ovo e da larva de último ínstar}

\section{Resumo}

Este estudo objetiva contribuir para o conhecimento dos estágios imaturos dos lepidópteros neotropicais. Nele é feito o detalhamento da morfologia das fases de ovo e de larva de Aucula magnifica (Schaus, 1904) (Lepidoptera: Noctuidae: Agaristinae), dando ênfase ao estudo das estruturas do córion e da quetotaxia da larva de último ínstar. Além disso é relatada a ocorrência da ação entomopatogênica do fungo Nomuraea rileyi (Farlow) Samson sobre suas larvas.

Palavras-chave: lagarta, fungo entomopatogênico, morfologia, quetotaxia.

\section{Introduction}

Agaristinae (Lepidoptera: Noctuidae) is a cosmopolitan subfamily, represented by 593 species, of which 130 occur in the Neotropical region (Heppner, 1991).

According to Poole (1989), Aucula magnifica was originally described by Schaus, in 1904, as Euthisanotia magnifica starting from specimens originating from Petrópolis, Rio de Janeiro, Brasil; Hampson (1910) complemented the original description of the adult starting from specimens from the British Museum. Silva et al. (1968) registered the occurrence of this species in Minas Gerais and Rio de Janeiro; recently, there were also made several registrations of the occurrence in Rio Grande do Sul (Specht and Corseuil, 1998; 2002; Viana and Costa, 2001; Specht et al., 2005).

Adults of A. magnifica (Figure 1) are beautiful and present hind wings with yellowish areas. In nature, the caterpillars were found feeding exclusively on Onagraceae: Epilobium arechavaletae H. Lév., 1911 (Biezanko et al., 1974); E. brasiliense Hausskn., 1879 (Biezanko and Ruffinelli, 1971); Fuchsia hybrida
Hort. Vilm. Blumengärtn, 1894; F. magellanica Lam., 1786; Oenothera longiflora Linn., 1771 (Biezanko and Ruffinelli, 1971; Biezanko et al., 1974) and Godetia sp. (Pastrana, 2004).

In spite of the frequent occurrence of A. magnifica in Rio Grande do Sul, little is known about the biology and morphology of the immature stages; this can also be said of the neotropical Agaristinae, standing out, only as references, publications on A. hilzingeri Berg, [1882] (Bourquin, 1958) and A. franclemonti Tood and Poole, [1981] (Rawlins, 1992).

Due to material readiness, in this study, the morphology of the egg and larva is detailed, also describing the occurrence of Nomuraea rileyi (Farlow) Samson fungi as a natural enemy of the larva.

\section{Material and Methods}

The immature stages of A. magnifica were obtained starting from a female collected on March $15^{\text {th }}, 2007$, 
in a luminous source near a vineyard in Faria Lemos, Bento Gonçalves, RS, by the second author. The insects were reared at the Laboratorio de Biologia of the Campus Universitário da Região dos Vinhedos (CARVI), Universidade de Caxias do Sul (UCS), Bento Gonçalves, under $25 \pm 1{ }^{\circ} \mathrm{C}, 70 \pm 10 \% \mathrm{RU}$ and 14 hours of photo phase; observations were carried out daily.

The eggs (Figure 2) were placed in Petri plates containing moistened filter paper. After the darkening, near eclosion, they were transferred to $200 \mathrm{~mL}$ glass flasks, containing Vitis labrusca Linn. - Vitaceae (grapevine branches) inserted in eppendorf tubes filled with water to maintain turgidity. The study of mycropile followed the method used by Angulo et al. (2006), which consisted of emptying the content of 10 eggs soon after the egg position, using an entomologic pin number 00 . The corium were disposed in individual plates with a drop of glycerinated alcohol at $40 \%$, covered with cover slips; they were photographed in a $400 \times$ optical microscope and from the picture, the drawing was elaborated (Figure 5). The morphology was compared to the description reported by A. franclemonti (Rawlins, 1992).

The description of the last larval instar (Figure 3) was made by auxilliary drawings, considering nomenclature and descriptions by Rawlins (1992), Merzheevskaya (1998) and Angulo et al. (2006), the setae maps of the thoracic and abdominal segments following the methodology described in Angulo et al. (2006), that consists of dissecting caterpillars of the last instar along the medium right dorsal line, submitting them to a clarification treatment through the action of a solution of $\mathrm{KOH}$ at $10 \%$. The 10 caterpillars used in the elaboration of the drawings were submitted to this procedure, and the teguments were disposed among sheets, for observation under stereo microscope.

All the material used in this study is conserved and kept in the collection of the Laboratory.

Contributions for description of the larval morphology were obtained in works of general knowledge such as Crumb (1956), Stehr (1987), Kitching and Rawlins (1998); however, because of the proximity of taxonomy, most of the aspects of the chaetotaxy were compared with the aspects illustrated and described by A. hilzingeri (Bourquin, 1958), for A. franclemonti (Rawlins, 1992) and Spodoptera cosmioides (Walker, 1858; Zenker et al., 2007).

\section{Results and Discussion}

The eggs (Figure 2) are sub spherical, slightly flattened, and plane based; their diameter is $1.1 \mathrm{~mm}$; translucent, sculptured corium. The shape is similar to that described by Rawlins (1992) for A. franclemonti eggs; however, soon after oviposition, they are whitish light green and at the end of incubation they become dark brown, as described for A. hilzigeri (Bourquin, 1958). They are individually deposited, in groups from three to ten, but never covered by pubescence, as observed for
A. franclemonti (Rawlins, 1992). The sculptury (Figure 5) has a primary elevated rosette, formed by 16 sub triangular, elongated cells which have the minor angle directed to the mycropile, distal region related to the most elevated mycropile, which is highlighted as a crown. Secondary rosette with intermediate elevation between the primary one and the others; composed of 17 sub triangular cells, bigger and conspicuous, mainly at the distal region, related to the mycropilar area. Tertiary 15 rectangular- cell rosette, slightly narrower cells in the sense of mycropile; from which they become progressively more flat-
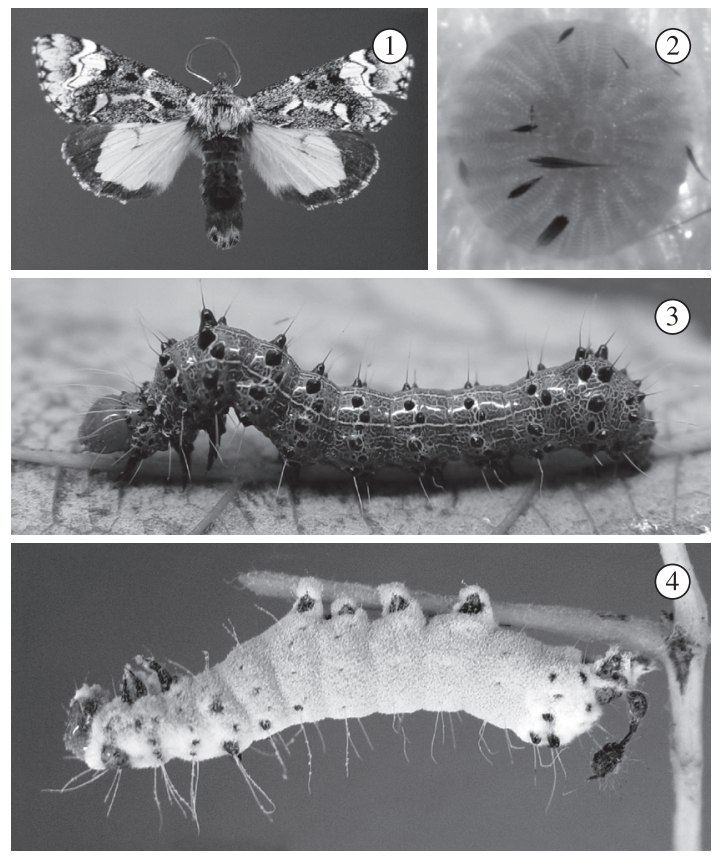

Figures 1-4. Aucula magnifica: 1 - Adult; 2 - Egg; 3 - Last instar caterpillar; 4 - Caterpillar covered by entomopathogenic Nomuraea rileyi (Farlow) Samson fungus.

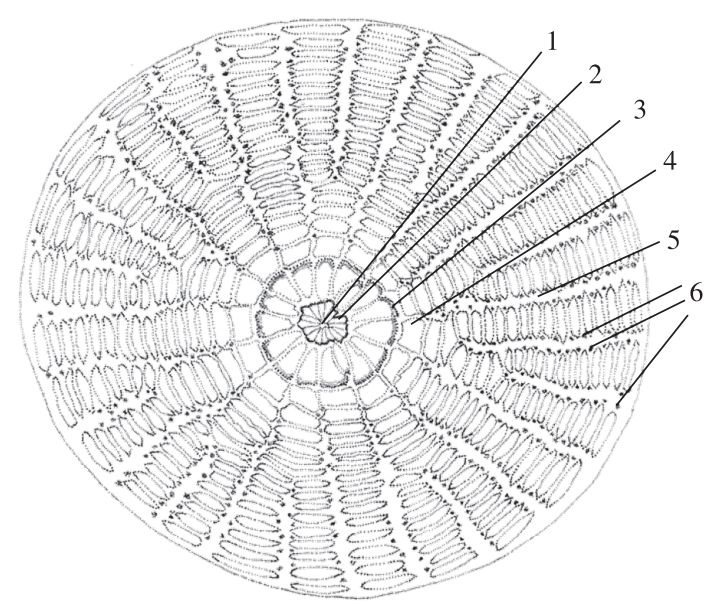

Figure 5. Aucula magnifica - Egg: 1 - Micropile; 2 - Primary cells; 3 - Secondary cells; 4 -Tertiary cells; 5 - Radial crests; 6 - Aeropyles. 
tened and, from the sixth to the tenth rosette, they can divide in two (the main part of them) or in three radial crystals, very well defined, formed by elongated cells of variable shapes, having more elevated borders, together with which aeropyles are observed, generally alternated among cells on one or the other side.

In the ten eggs studied, 27 crests were observed, which is a higher number than the 22-25 found by Rawlins (1992) for A. franclemonti. In the same way, it was observed that in A. magnifica only half of the crests reach the mycropilar rosette too.

From the first instar, the larvae have a reddish-brown head and body tegument, with very big black pinaculae, with long and transparent bristles. Both thoracic legs and larvopodes are blackish. Mid-dorsal and sub-dorsal lines are whitish and interrupted in some segments. These characteristics are shared by A. hilzigeri (Bourquin, 1958) and A. franclemonti (Rawlins, 1992).

Last (sixth) instar caterpillars (Figure 3), similar to A. franclemonti (Rawlins, 1992), are approximately $34.76 \mathrm{~mm}$ long, and the widest cephalic capsule is $4.25 \mathrm{~mm}$.

Head (Figure 3) hypognate, reddish-dark brown, often blacker at the extremity; brown clypeus, with dark brown ventral margin; light brown adfrontal area; light and well-defined ecdysal area; orange or yellowish vertex (epicranial notch) and gena; same colour for fore clypeous and antenna base; brown labrum, with darker superior portion. Adfrontal sutures along fore clypeous margin and epicranial suture towards the tail to the epicranial notch.

Regarding chaetotaxy, the head (Figures 6-8) has bristle A1 located between the adfrontal area and the third stem; bristle A2 located just above bristle A1 (right), between adfrontal area and the first stem; bristle A3 located just above the first stem, forming a triangle together with the other bristles of the former group; fore pore Aa above and between bristles A2 and A3. 3 stem or ocellar bristles: S1 above and between fourth and sixth stem; S2 lateral to first stem; S3 post-dorsal to sixth stem, between this and bristle S3, the pore is located Sa. Three sub stem bristles SS: SS1 more ventral and close to the jaw, SS2 between SS1 and SS3; SS3 more distal to antenna; sub stem pore Ssa between SS2 and SS3. Fore bristles (F) represented only by F1, in the front midinferior region; pore $\mathrm{Fa}$ more inferior and more central (medium) than F1, in the front. Two adfrontal bristles $\mathrm{AF} 1$ and AF2, being AF1 more medium and AF2 more superior; pore $\mathrm{AFa}$ between bristles $\mathrm{AF} 1$ and $\mathrm{AF} 2$. Two clypeus bristles $(\mathrm{C})$ : $\mathrm{C} 1$ located in the inferior vertex off clypeus and ventral to C2. Bristle L1 (lateral) at the genal portion of cephalic capsule; pore La on the right of L1. Hind bristles $(P)$ at the superior face of the head, between the lateral and superior adfrontal region: $\mathrm{P} 1$ close to ecdysal line; $\mathrm{P} 2$ superior to $\mathrm{P} 1$; pore $\mathrm{Pa}$ inferior and ventral to $\mathrm{P} 1$ and $\mathrm{L} 1$; pore $\mathrm{Pb}$ superior to $\mathrm{P} 1$ and inferior on the left of P2. CD (cephalus-dorsal) or MD (microdorsal) according to Stehr (1987) are fairly short, located

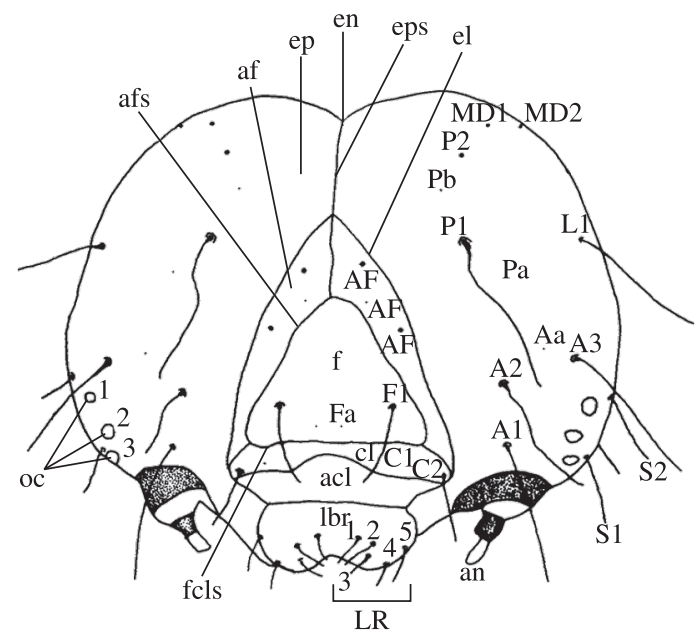

Figure 6. Aucula magnifica - last instar larvae, frontal view of the head. el) ecdysal line; ne) epicranial notch; eps) epicranial suture; ep) epicranium; af) adfrontal area; afs) adfrontal suture; oc) stems; f) front; cl) clypeum; acl) anteclypeum; fcls) frontclypeum suture; lbr) labrum; LR) labrum bristles; an) antenna; MD1-MD2) microdorsal bristles; P1-P2) posterior bristles; $\mathrm{Pa}-\mathrm{Pb}$ ) head posterior pores; S1-S2) stematal bristles; A1-A3) anterior bristles; Aa) anterior pore; AF1-AF2) adfrontal bristles; Afa) adfrontal pore; L1) lateral bristle; F1) frontal bristle; Fa) frontal pore; C1-C2) clypeum bristles.

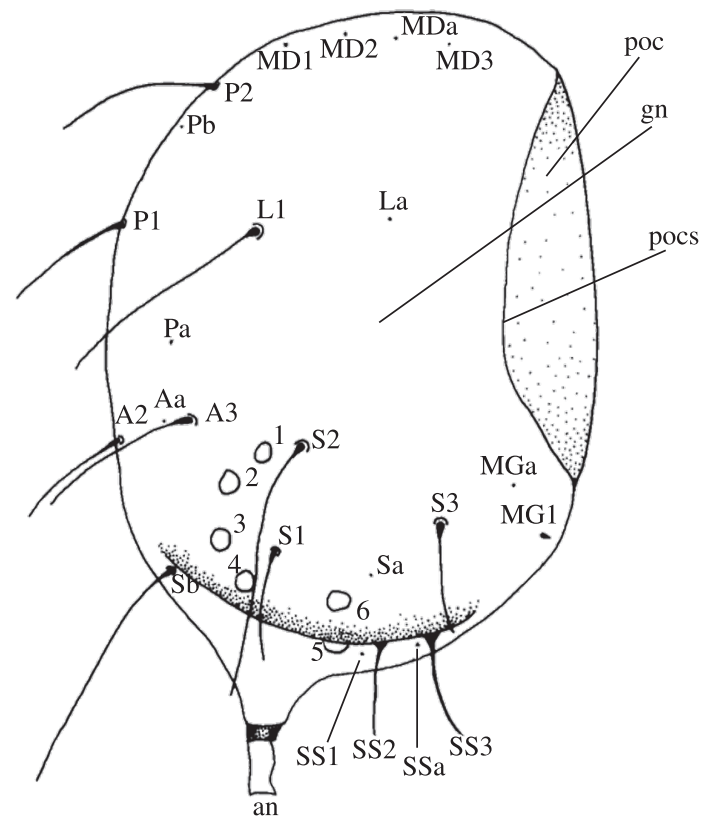

Figure 7. Aucula magnifica - last instar larvae head lateral view: 1-6) ocelli; an) antenna; gn) gena; MD1-MD3) microdorsal bristles; Mda) microdorsal pore; MG1) microgenal bristle; MGa) microgenal pore; $\mathrm{P} 1-\mathrm{P} 2$ ) posterior bristles; $\mathrm{Pa}-\mathrm{Pb}$ ) head posterior pores; $\mathrm{S} 1-\mathrm{S} 3$ ) Stematal Bristles; Sa$\mathrm{Sb}$ ) stematal posterior pores; SS1-SS3) substematal bristles; SSa) substematal pore ; A2-A3) anterior bristles; Aa) anterior pore; L1) lateral bristle; La) lateral pore; poc) postocciput; pocs) postoccipital suture. 


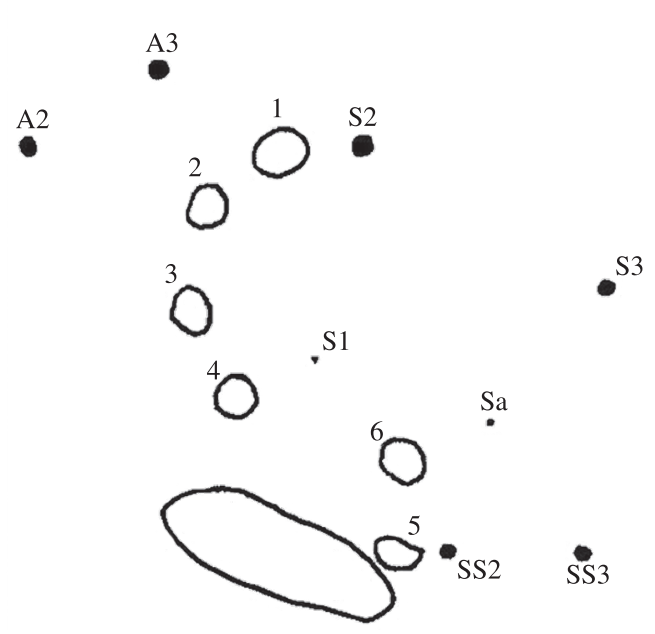

Figure 8. Aucula magnifica - last instar larvae - amplified ocular area. 1-6) stems; A2 - A3) anterior bristles; Sa) posterior stematal pore; S1 - S3) stematal bristles; SS2 - SS3) substematal bristles.

at the superior portion of the head. MD2 between MD1 and MD3, closer to MD1. Pore MDa between MD2 and MD3. Bristle MG1 (micro genal) is short and close to the maxillae base; absent MG2; MGa pore above and in front of MG1. At labrum, there are 5 pairs of bristles: 1 ventral; 2 intermediate; 1 marginal inferior and another superior marginal related to the former. Developed and very conspicuous adenosma.

Maxilar (Figure 9) similar to the one described for A. franclemonti (Rawlins, 1992) highlighting as main differences, the internal tooth which presents two tops and less developed hind condylus mandibles.

Similar to A. franclemonti (Rawlins, 1992), A. magnifica has a complex hypopharingeal (Figures 10-12) tubular with two projections between a longitudinal furrow in the dorsal area delimiting the spinner, with plain apix, differently from the wavy one in A. franclemonti (Rawlins, 1992). The structure of the antenna (Figure 13) match those of A. franclemonti (Rawlins, 1992).

A. magnifica (Figure 3) presents body epidermis ornamentation varying from light brown to black; mid-dorsal and lateral-dorsal lighter lines than body and spots, which is because they are little evident; brown prothoracic and anal plates, lighter than body; more conspicuous spiracular and sub-spiracular areas at first instars and less evident in the latter because they are darker; brown larvopods and dark brown thoracic legs; light and translucent bristles implanted in dark and black chalazas (Figure 14).

On the thorax, the lateral-dorsal stripe is more conspicuous than the mid-dorsal one, but it becomes inconspicuous in the thoracic plate; where it presents just the mid-dorsal stripe. Apparently it does not have a cervical

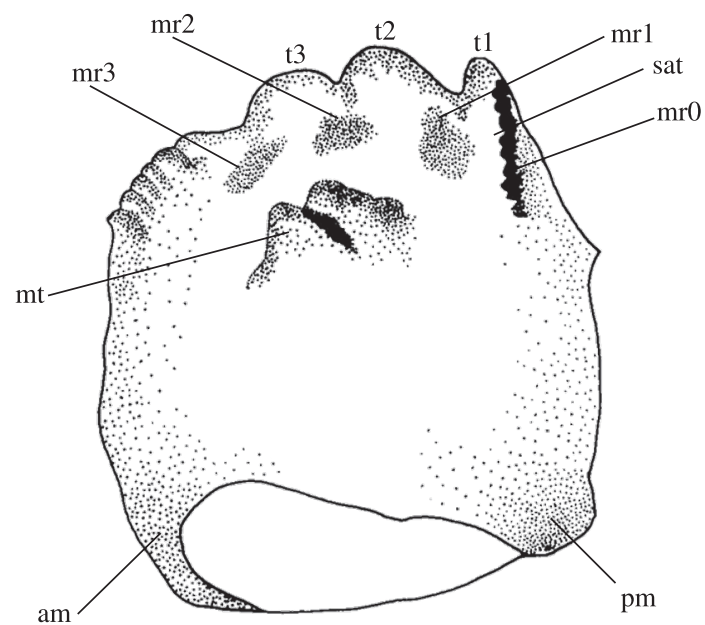

Figure 9. Aucula magnifica - last instar larvae - mandible: amc) anterior mandible condylous $\mathrm{mt}$ ) inner tooth; pmc) posterior mandible condylous; mr0) exterior top mandible; mr1-mr3) inner top mandible; sat) subapical groove; $\mathrm{t} 1$ - $\mathrm{t}$ 3) apical teeth.



Figure 10. Aucula magnifica - last instar larvae - anteroventral view of hypopharingeal complex. be) stem base; dst) distipe; mp1-mp3) palpo maxilar segments; lg) laciniogalea; sell) conical lateral laciniogalea sensilo; Mx7) maxilae apical bristle; seml) lateral conical laciniogalea sensilo; MPb1) lateral pore of the second palpo maxilar segment; $\mathrm{MPb} 2$ ) medial sensilo of second palpo maxilar segment; MPa) basal segment of palpo maxilar pore; Mx1-Mx3) maxilar estipe bristles; Mx4) first palpo maxilar segment bristle; LBa-LBc) palpigerum pores; fi) weaver; PM1) postmental bristle; LP1) apical bristle of basal palpo labial segment; lp1) palp labial distant segment; LGa) laciniogalea pore; MPc) palp maxillae distal segment pore; prm) premento.

region, being the prothoracic plate immediately after the head. Very clear and conspicuous region between metathorax and the first abdominal segment in caterpillars at the first instars. At the last instars, colour becomes darker and plates more conspicuous. Light-coloured mid-dorsal and sub-spiracular stripe. Lighter than body belly. Prothorax spiracles and eighth uromere approximately twice as big and more conspicuous than the others. 


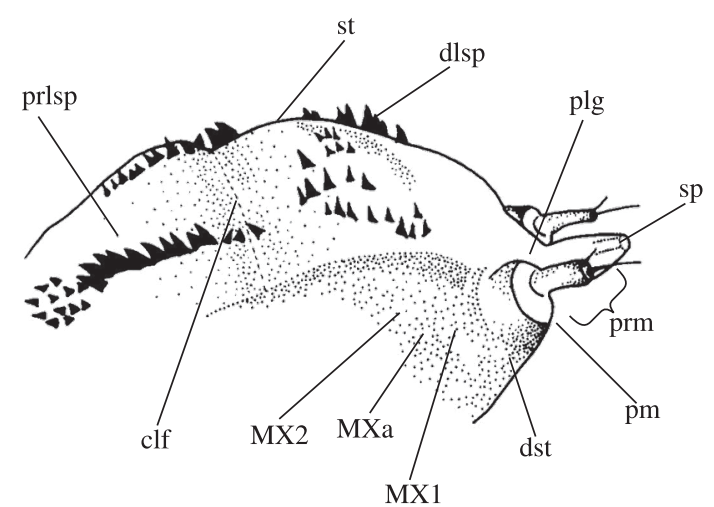

Figure 11. Aucula magnifica - last instar larvae - hypopharingeal complex (lateral view). epl) proximal-lateral spiracles; sth) hypopharingeal transversal suture; ed) distolateral spiracles; p) palpigerum; fi) spinner; prm) premento; pm) postmento; dst) distipe; MX1- MX2) maxillae stipe bristles; MXa) stipe base pore; st) transversal suture.

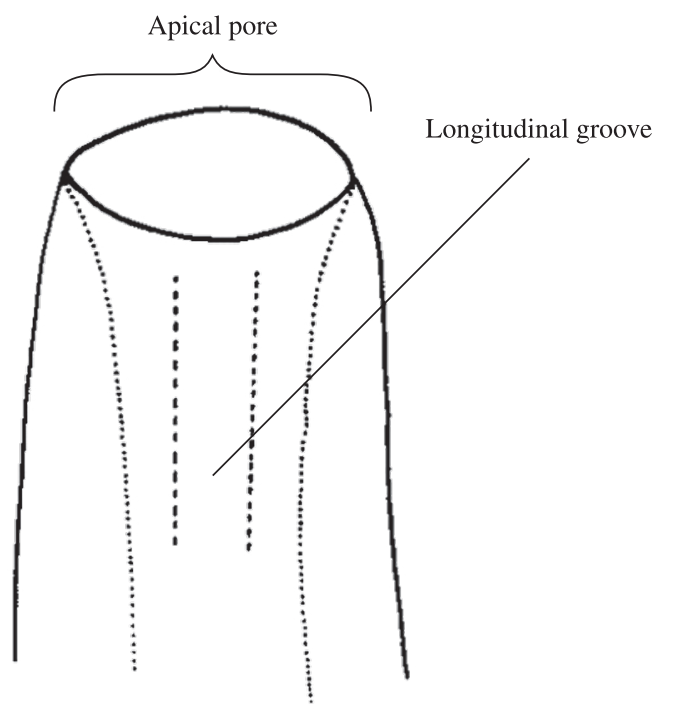

Figure 12. Aucula magnifica - last instar larvae - spinner front view.

Thorax chaetotaxy (Figure 15) is characterised by dorsal bristles (D) of similar length in all segments, corresponding to that represented for $A$. franclemonti (Rawlins, 1992); sub-dorsal bristles (SD1-SD2) in the prothorax (T1) close to thoracic plate directed horizontally with a light bending, of less than $45^{\circ}$ directed to mesothorax (T2), being SD2 more conspicuous than SD1 in all segments; SD1-SD2 vertically lined in mid and metathorax (T2-T3); D1 and D2 vertically lined in T1-T3; two sub-belly bristles (SV) appeared in T1 and only one $\mathrm{SV}$ in the segments T2-T3; lateral bristles (L2) present at T1-T2 and L3 in the segments T2-T3; A. franclemonti has L2 only in T1 segment (Rawlins, 1992). SD1 and SD2 bristles in the same chalazae in the pro thorax sepa-

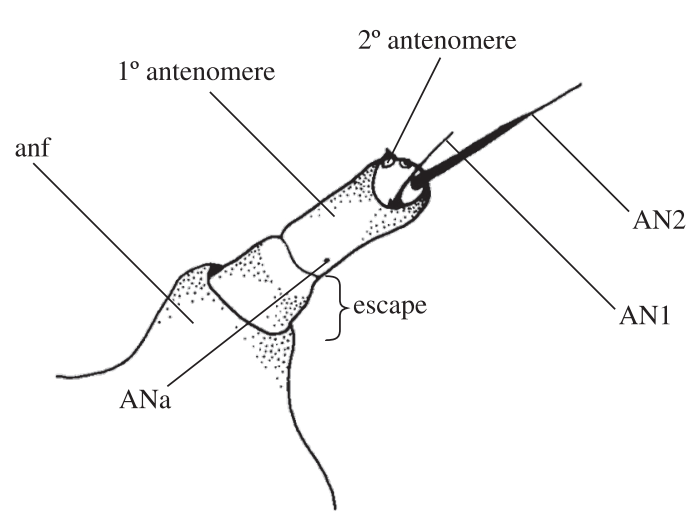

Figure 13. Aucula magnifica - last instar larvae - antenna. AN1-AN2) first antenomere bristles; ANa) first antenomere pore; anf) antennipherous.

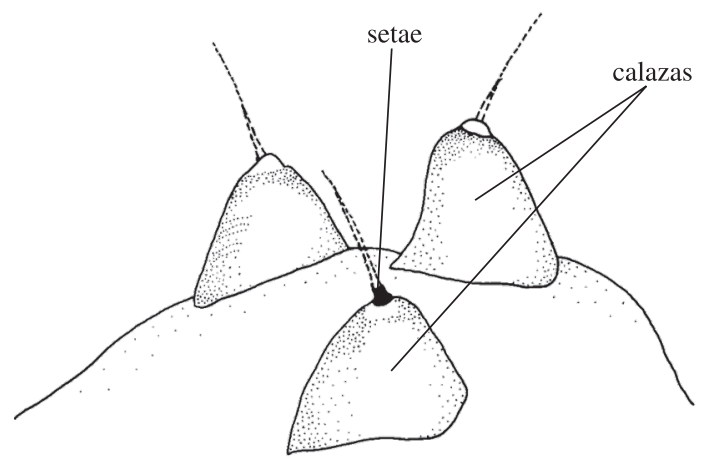

Figure 14. Aucula magnifica - Chalazas.

rated at mid and meta thorax. In T1 the thoracic plate has besides D1 and D2, fore dorsal vertical bristles (XD2 e XD1), respectively. Between XD2 and XD1 there are $\mathrm{XDa}$ and XDc pores, bigger ones near XD1, XDa further between $\mathrm{D} 1$ and XD2, there is XDb. At the margin of the plate, distal to the head, there is MXD1. Absent spiracles in T2-T3 and relatively conspicuous in T1, but smaller than in the eighth uromere. MD1 between D1 and D2 in T2 and D1 in T3, in an upper position, next to D1. Subdorsally, between SD2 from the segments T1$\mathrm{T} 2$, there are inconspicuous MSD1 and MSD2, bent to T1. Between T2-T3, below MD1, MD2 highlights; with vertical bending related to mid thorax. The main part of the bristles is in the chalazas, significantly conspicuous or either inconspicuous. Rawlins (1992) attributed, for $A$. franclemonti, more emphasis to the presence of two SV bristles in the A1, two SV bristles in the A7 and a SD1 normal, less conspicuous bristle, in the A9.

Thoracic legs (Figures 16-17) similarly to A. franclemonti (Rawlins, 1992) have divided thighs in fore and hind sclerite in its anteroventral extended suture with coccyx condyle articulated with the trochanter. This also presents five primary coccyx bristles: one of them $(\mathrm{C} 1)$ in the anterior coccyx sclerite and four $(\mathrm{C} 2-$ 


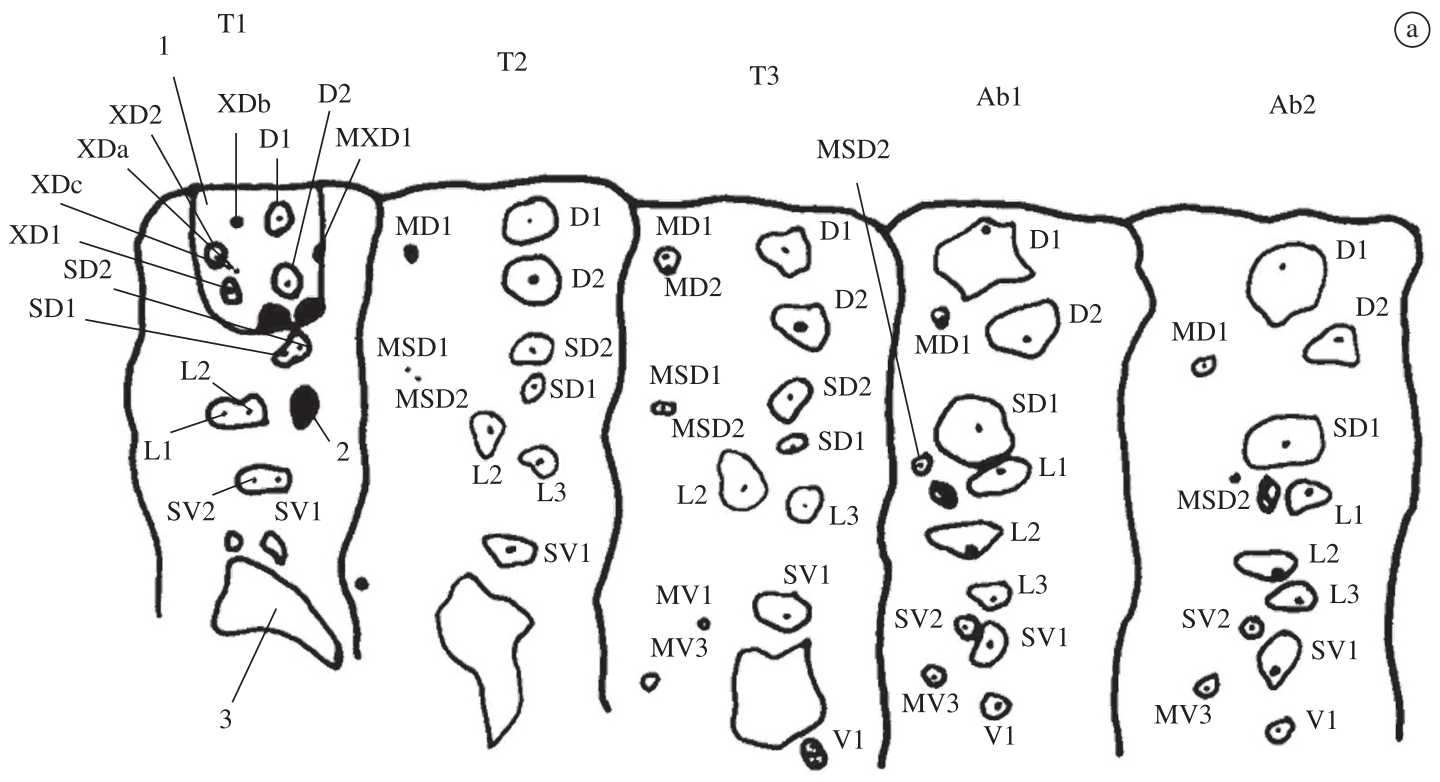

Ab6



Figure 15. Aucula magnifica - last instar larvae - Thorax and abdomen setal map T1) prothorax; T2) mesothorax; T3) metathorax; Ab1-Ab2) first and second uromeres; Ab 6-Ab10) sixth to tenth uromeres: 1) thoracic plate; 2) spiracle; 3) thoracic leg; 4) larvopod; 5) annal plate; D1-D2) dorsal bristles; SD1-SD2) subdorsal bristles; XDa-XDc) Prothorax antero dorsal pores; XD1-XD2) Dorsal anterior bristles; L1-L3) lateral bristles; MXD1) prothorax posterior bristle; MD1-MD2) dorsal bristle (proprioceptora dorsal); MSD1-MSD2) subdorsal bristles; MV1-MV3) mid-ventral bristles; V1) ventral bristle; SV1SV4) subventral bristles; LAa) lateral pore (proprioceptor lateral). PP1) parannal bristle.

C5) in the posterior coccyx sclerite, numbered in a sequence around the thigh; a small one in the anterior margin of the coccyx sclerite close to the suture (MC1); a basal reduced one for bristle $\mathrm{C} 1$ (DC1) and similar reduced (DC2) basal for a $\mathrm{C} 5$. Three bristles in membrane intervals between the trochanter and the femur base, numbered in a sequence around the position seg- ment relatively anterodorsal for coccyx suture (MTR1), for an anteroventral positioned below the coccyx suture (MTR2), for the posteroventral position (MTR3); pore (MTRa) situated between MTR1 and MTR2. The femur does not have pores; it has two bristles, anterior (FE1) and posterior (FE2). Tibia with posterodorsal simple pore (T1a) and six bristles wrapping the apix, numbered 

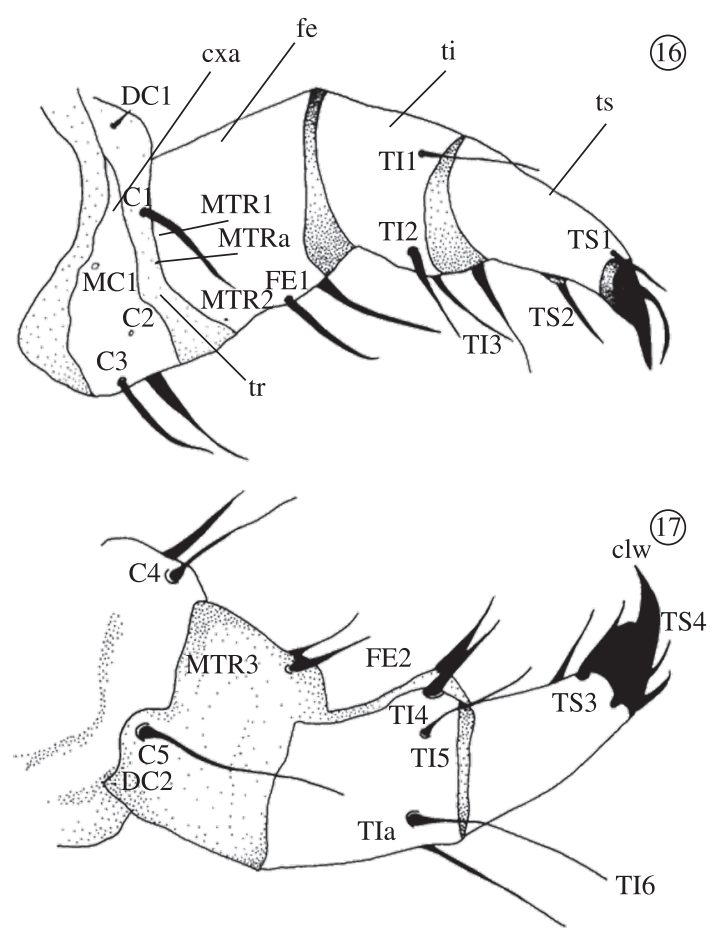

Figure 16-17. Aucula magnifica - Prothoracic leg anterior view (16) and posterior view of prothoracic leg (17). C1-C3) anterior coxal sclerite bristles; $\mathrm{C} 4-\mathrm{C} 5$ ) posterior coxal sclerite bristles; clw) pretarsal claw; cxa) anterior coxal sclerite; MTR1-MTR3) trochanter bristles; MTRa) anterodorsal trochanter pore; ti) shinbone; T11-T16) shinbone bristles; TIa) tibial pore; tr) trochanter; ts) tarsum; TS1-TS4) tarsal bristles; fe) femur; FE1-FE2) femural bristles; MC1) coxal sclerite bristle; DC1-DC2) thigh dorsal sub-primary bristles.

in a continuous sequence: anterodorsal (T11), anterolateral (T12), anteroventral (T13), posteroventral (T14), posterolateral (T15), posterodorsal (T16). Tarso with four bristles, numbered as tibia: anterodorsal (TS1, one small bristle), anteroventral (TS2), posteroventral (TS3, only distanced of TS2) and posterodorsal (TS4, longer than TS1); strong and slightly flattened bristles TS2, TS3 and TS4.

Abdomen with dark conspicuous chalazes with big, translucent bristles. The mid-dorsal stripe is narrower and less evident than the latero-dorsal; the sub-spiracle one is clear and conspicuous, with some irregular points. It has larvopods from A3 to A6 and A10. According to Merzheevskaya (1998), the hooks are uniordinals, and are a total of 27 in each larvopod (Figure 18).

Regarding chaetotaxy, the abdome (Figure15) presents four bristles $\mathrm{SV}$ in the A10, three from the A2 to A6, two in the A1, seventh and A8 and one in the A9. Bristle L1 posterior to spiracle from A1 to A6 and A8.

This study showed a big similarity between last instar caterpillars from A. magnifica and A. franclemonti, but more comparisons were not done due to the absence

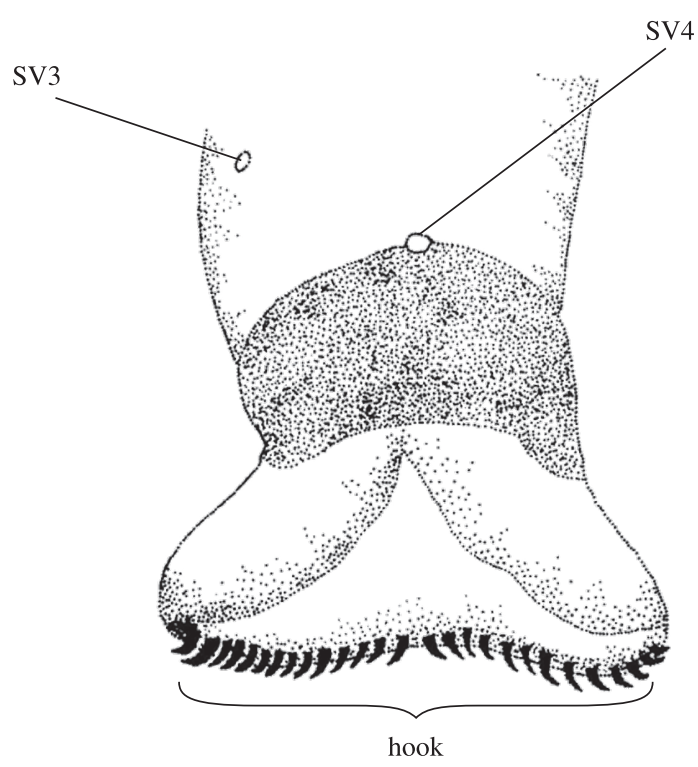

Figure 18. Aucula magnifica - Ventral view of a larvopod. SV3- SV4) subventral setae.

of detailed description of structures as egg and larvopods by Rawlins (1992).

The morphologic characterisation of the pupa phase was not done because all the specimens died before metamorphose, as they were attacked by an entomopathogenic fungus isolated and identified as Nomuraea rileyi (Farlow) Samson (Figure 4), kept in the Laboratório de Controle de Pragas of Instituto de Biotecnologia of Universidade de Caxias do Sul, under register number UCS 03.

Despite the fact that this entomopathogenous is known for infecting caterpillars of various noctuidaeplague (e.g. Alves, 1998; Boucias et al., 2000; Sujii et al., 2002; Devi et al., 2003; Srisukchayakul et al., 2005), this is the first record of its occurrence attacking Agaristinae specimens.

Acknowledgements - We are grateful to CNPq for the scholarship granted to the first author; to UCS for the scholarship granted to the second author; to FAPERGS for the financial aid.

\section{References}

ALVES, SB., 1998. Fungos Entomopatogênicos. In ALVES, SB. (Ed.). Controle microbiano de insetos. Piracicaba: FEALQ. p. 289-381.

ANGULO, AO., OLIVARES TS. and WEIGERT GT., 2006. Estados inmaduros de Lepidópteros Nóctuidos de importancia económica agrícola y forestal en Chile (Lepidoptera: Noctuidae). Concepción: Universidad de Concepción.

BIEZANKO, CM. and RUFFINELLI A., 1971. Fauna de Lepidoptera del Uruguay: Agaristinae, Noctuidae, Thiatiridae. Montevideo: Ministério de Ganadería Y Agricultura. p. 1-31. (Serie Zoologia Agrícola, Publ. Tecn. 2) 
BIEZANKO, CM., RUFFINELLI, A. and LINK, D., 1974. Plantas y otras substancias alimentícias de las orugas de los Lepidópteros Uruguayos. Revista do Centro de Ciências Rurais, vol. 4, no. 2, p. 107-148.

BOUCIAS, DG., TIGANO, MS., SOSA-GOMEZ, DR., GLARE, TR. and INGLIS, PW., 2000. Genotypic properties of the Entomopathogenic fungus Nomuraea rileyi. Biological Control, vol. 19, no. 2, p. 124-138.

BOURQUIN, F., 1958. Ocho notas sobre metamorfosis de Lepidópteros. Acta Zoológica Lilloana, vol. 16, p. 237-272.

CRUMB, SE., 1956. The larvae of the Phalaenidae. Washington: United States Department of Agriculture. p. 1-356. (Technical Bulletin, 1135)

DEVI, PSV., PRASAD, YG., CHOWDARY, DA., RAO, LM. and BALAKRINSHNAN, K., 2003. Identification of virulente isolates of the entomopathogenic fungus $N$. rileyi $(\mathrm{F})$ Samson for the management of Helicoverpa armigera and Spodoptera litura. Mycopathologia, vol. 156, no. 4, p. 365-373.

HAMPSON, GF., 1910. Catalogue of the Lepidoptera Phalaenidae in the British Museum. London: Taylor and Francis. (vol. 9)

HEPPNER, JB., 1991. Faunal regions and the diversity of Lepidoptera. Tropical Lepidoptera, vol. 2, suppl. 1, p. 1-85.

KITCHING, IJ. and RAWLINS, JE., 1998. The Noctuoidea. In KRISTENSEN, NP. (Ed.). Lepidoptera, moths and butterflies. Berlin: Walter de Gruyter. p. 355-401. (Handbook of Zoology, IV)

PASTRANA, JA., 2004. Lepidópteros Argentinos: sus plantas hospedadoras y otros sustratos alimentícios. Buenos Aires: Sociedad Entomológica Argentina.

POOLE, RW., 1989. Noctuidae. In HEPPNER, JB. (Ed.) Lepidopteroum catalogus. New York: Brill.

RAWLINS, JE., 1992. Life history and Systematics of the west Andean moth Aucula franclemonti with description of a new species from Ecuador (Lepidoptera: Noctuidae: Agaristinae). Journal of the New York Entomological Society, vol. 100, no. 2, p. 286-310.
SCHAUS, W., 1904. New Species of American Heterocera. Transactions of the American Entomological Society (Philadelphia), vol. 30, no. 2, p. 135-178.

SILVA, AGA., GONÇALVES, CR., GALVÃO, DM., GONÇALVES, AJL., GOMES, J., SILVA, MM. and SIMONI, L., 1968. Quarto catálogo dos insetos que vivem nas plantas do Brasil: seus parasitos e predadores. Rio de Janeiro: Ministério da Agricultura. (parte II, tomo I)

SPECHT, A. and CORSEUIL, E., 1998. Novas ocorrências de noctuídeos (Lepidoptera, Noctuidae) no Rio Grande do Sul, Brasil. Biociências, vol. 6, no. 1, p. 123-129.

SPECHT, A. and CORSEUIL, E., 2002. Diversidade dos Noctuídeos (Lepidoptera, Noctuidae) em Salvador do Sul, Rio Grande do Sul, Brasil. Revista Brasileira de Zoologia, vol. 19, suppl. 1, p. 281-298

SPECHT, A., TESTON, JA., DI MARE, RA. and CORSEUIL, E., 2005. Noctuídeos (Lepidoptera, Noctuidae) coletados em quatro áreas estaduais de conservação do Rio Grande do Sul, Brasil. Revista Brasileira de Entomologia, vol. 49, no. 1, p. $130-140$

SRISUKCHAYAKUL,P., WIWATB, C. andPANTUWATANAC, S., 2005. Studies on the pathogenesis of the local isolates of Nomuraea rileyi against Spodoptera litura. Science Asia, vol. 31 , no. 3, p. 273-276

STEHR, FW., 1987. Order Lepidoptera. In STEHR, FW. (Ed.). Imature insects. Dubuque: Hunt Publishing Company. p. 288-596. (vol. 2)

SUJII, ER., CARVALHO, VA. and TIGANO, MA., 2002. Cinética da esporulação e viabilidade de conídios de Nomuraea rileyi (Farlow) Samson sobre cadáveres da lagarta-da-soja, Anticarsia gemmatalis Hübner (Lepidoptera: Noctuidae), em condições de campo. Neotropical Entomology, vol. 31, no. 1, p. 85-90.

VIANA, TMB. and COSTA, EC., 2001. Lepidópteros associados a duas comunidades florestais em Itaara, RS. Ciência Florestal, vol. 11 , no. 1 , p. 67-80.

ZENKER, MM., SPECHT, A. and CORSEUIL, E., 2007. Estágios imaturos de Spodoptera cosmioides (Walker) (Lepidoptera, Noctuidae). Revista Brasileira de Zoologia, vol. 24, no. 1, p. 99-107. 